\title{
In vivo evaluation of the protein quality of lyophilized egg white as substitute for casein in elaboration of an experimental diet based on AIN93
}

Wenicios Ferreira-Chaves ${ }^{1}$, Isabeli Lins Pinheiro ${ }^{1,2}$, Carolina Cadete Lucena-Cavalcanti ${ }^{1}$, Alvaro do NascimentoBarreto', Breno José da Silva1, Raul Manhães de Castro', Raquel da Silva Aragão, ${ }^{1,2}$

1 Unit of Studies in Nutrition and Phenotypic Plasticity, Department of Nutrition, Universidade Federal de Pernambuco, 50670901, Recife, Brazil.

2 Physical Education and Sports Sciences Nucleus, Universidade Federal de Pernambuco, Vitria de Santo Antão, 55608-250, Brazil.

\author{
Correspondence \\ R.S. Aragão \\ E-mail: raquel.aragao@ufpe.br \\ Phone: +55 81 99504-4527
}

Received: 28 January 2020

Accepted: 16 July 2020

Published on-line: 25 October 2020

\section{Resumen}

Evaluación in vivo de la calidad proteica de la clara de huevo liofilizada como sustituto de la caseína de una dieta experimental basada en la AIN93

El objetivo del estudio fue evaluar in vivo la calidad de la proteína de la clara de huevo liofilizada como sustituto de la caseína en la dieta AIN93. Se separaron ratones Wistar machos $(n=30)$ según las dietas: caseína (CS), clara de huevo (EW) y sin proteína (PF). Se evaluó el crecimiento somático y la ingesta de alimentos. Se midieron la relación de eficiencia de proteína, la relación neto de proteína, el perfil bioquímico en suero, los pesos de los órganos y de los tejidos. La relación de eficacia de proteína, muestra que EW presenta un alto valor biológico. Sin embargo, EW mostró un crecimiento menor que el CS. El peso relativo de los órganos y la creatinina sérica se elevaron en el grupo EW. Por lo tanto, EW promueve la reducción del crecimiento, a pesar de la mayor ingesta.

Palabras clave: Dieta Experimental; Perfil bioquímico; Mediciones murinométricas; Relación de eficiencia de proteínas; Relación neta de proteínas.

\begin{abstract}
The aim of the study was to evaluate in vivo the quality protein of lyophilized egg white as a substitute for casein in the AIN93 diet. Male Wistar rats $(n=30)$ were separated according to diets: casein (CS), egg white (EW) and without protein (PF). Somatic growth and food intake were assessed. Protein Efficiency Ratio, Net Protein Ratio, serum biochemical profile, organs and tissue weight were measured. Protein efficacy assessment shows that EW presents high biological value. However, EW group showed lower growth than the CS. The relative weight of organs and serum creatinine were elevated in the EW. Thus, EW promotes reduced growth and changes the weight of organs and tissues, despite the higher relative food intake.
\end{abstract}

Key words: Experimental Diet, Biochemical profile, Murinometric measurements, Protein efficiency ratio, Net protein ratio. 


\section{Introduction}

Feeding represents one of the environmental variables with greatest repercussion in the adequate growth and development of an organism, including experimental animals, such as rodents (Reeves 1993, Gibbs \& Smith 2016). It is established in literature that the insufficient or exacerbated supply of nutrients, such as proteins or lipids, can promote structural and functional alterations of organs and/or tissues (Morgane et al. 1993, Mark et al. 2011). These changes seem to be aggravated during critical period, when intense processes of cellular hyperplasia and hypertrophy occur, causing repercussions on the adult life of these mammals (Desai \& Hales 1997). This critical phase, when it is recommended to offer a growth diet, ranges from the perinatal period (gestation and lactation) to approximately 50 postnatal days in rodents (Reeves 1993). The American Institute of Nutrition (AIN) has pioneered in development of nutritional recommendations for rodents through the elaboration of AIN76 diet (Reeves 1993). However, research has identified an imbalance in the mineral and vitamin mixes, form and amount of fat, and sulfur amino acid deficiency in the AIN76 composition, that was later reformulated in AIN93 to growth (AIN93G) or maintenance phase (AIN93M) (Reeves 1993). Currently, the AIN93 is still considered the reference in the nutritional recommendation for rodents (Reeves 1993).

Casein has been widely used as a protein source of purified diets (AIN93), though there are other animal source of high-quality protein as cow's milk or lyophilized egg that are less used (Hoffman \& Falvo 2004). Protein from animal source presents higher bioavailability and better essential amino acid (EA) profile, obtained exclusively by diet (Chalvon-Demersay et al. 2017). However, casein usually promotes a high cost of production in experimental diets despite its high biological value (Hoffman \& Falvo 2004). To reduce costs, the industries have produced commercial chow diets based on vegetable sources of protein, as soybean. Though soybean protein quality is like animal sources (Brown \& Setchell 2001), they need to use a protein content above the recommendation. However, soybean and other plant proteins have high levels of harmful substances, such as enzymatic inhibitors, pesticides and other contaminants used during the production process (Gerage et al. 2017, Uyemura et al.
2017). In addition, commercial chow diets also contain high levels of sodium in their composition, impairing the animal's hemodynamic homeostasis (Martus et al. 2005).

In this sense, it is necessary to evaluate through different methods the quality and composition of new ingredients to be used in the elaboration of experimental diets (Millward 2012, Moraes et al. 2012).Thus, as for the analysis of the protein quality of new ingredients, casein is considered the gold standard for comparison through the application of chemical or biological methods (Moraes et al. 2012, Neufeld et al. 2018). Among the in vitro methods, we highlight the chemical score obtained through physicalchemical evaluation and subsequent comparison of protein test versus the standard (Neufeld et al. 2018). However, this method is limited to quantification of amino acids making it impossible to infer their bioavailability in the organism (Neufeld et al. 2018). On the other hand, the in vivo methods, among them the net protein ratio and the protein efficiency ratio, seek to assess quality through the relationship between protein intake and animal growth (Moraes et al. 2012). These methods present greater reproducibility and have as main advantage to evaluate the organic repercussions and the bioavailability of the protein test (Derzi et al. 2012, Moraes et al. 2012). In this context, through these methods some ingredients had their protein quality attested, such as sorghum and other cereals fortified with soy (Moraes et al. 2012, Acevedo-Pacheco \& Serna-Saldívar 2016).

In relation to egg white (EW) protein, some experimental studies have shown no difference in body weight gain and dietary intake of adult rat fed with diet based on egg white protein in comparison to diet based on casein (Matsuoka et al. 2008). The egg white protein diet was still able to reduce total serum and hepatic cholesterol without altering the other cholesterol fractions, besides not changing liver and muscle weight in relation to casein diet (Matsuoka et al. 2008, Norton et al. 2016). Regarding muscle protein synthesis, studies have shown that there is no difference between the stimulus promoted by diet with whey as protein source in comparison to egg white diets in both increase the serum concentration of EA (Norton et al. 2016, Matsuoka et al. 2017). Another advantage is that the lyophilized egg white diet does not require methionine supplementation, since this ingredient contains an elevated amount 
of EA in its composition (Reeves 1993). Despite these results, the studies cited do not validate the protein quality of lyophilized egg white through biological assays, because they do not evaluate the animals during the growth phase or adjust the percentage of dietary protein. Thus, the present study aimed to evaluate the in vivo protein quality of lyophilized egg white as a substitute for casein in the elaboration of an experimental diet based on AIN93G used during gestation, lactation, and growth periods.

\section{Material and methods}

All the experimental procedures performed in rats agreed with Guidelines for the Care and Use of Laboratory Animals and they had been approved by UFPE ethics committee on register $n^{\circ} 0043 /$ 2018.

\section{Animals and diets}

Thirty male albino Wistar rats (Rattus norvergicus Berkenhout, 1769) newly weaned, weighing 45$65 \mathrm{~g}$ and 25 day of age were obtained from the Department of Nutrition, Universidade Federal de Pernambuco, Brazil. These animals were housed in individual cages maintained at constant temperature $\left(22 \pm 1{ }^{\circ} \mathrm{C}\right)$ and controlled lighting cycle (dark 08:00 am. until 8:00 pm.), water and food were offered ad libitum. First, we elaborated a diet based on AIN93G whose protein source was egg white (Reeves 1993). Then both diets with casein and egg white were reformulated to reduce their protein content to $10 \%$. This percentage of protein is used to evaluation of in vivo protein quality. A third diet protein-free was used to evaluate net protein ratio. Pellets of all experimental diets were analyzed to confirm their composition (Table 1). The experimental diets were analyzed following recommendations from Adolf Lutz Institute (2008) for centesimal composition. Thus, protein content was measured by Kjeldahl method, lipids content was determined by Soxhlet method and carbohydrate was determined through difference (Adolf Lutz Institute, 2008).

\section{Murinometric measurements}

Body weight (BW) and body length were measured weekly from the $28^{\text {th }}$ to the $56^{\text {th }}$ day of life. Body weight was measured using a semi-analytical balance (Marte ${ }^{\circledR}$; accuracy: 0.01g). Body length was measured using a calliper as the distance from the muzzle until anus (KINGTOOLS ${ }^{\circledR}$; accuracy: $0.05 \mathrm{~mm}$ ). Body mass index (BMI) represents the distribution of body weight by area and was calculated by the formula:

$\mathrm{BMI}=\mathrm{BW}(\mathrm{g}) /$ longitudinal axis $\left(\mathrm{cm}^{2}\right)$

\section{Food intake measurements}

Animals food intake was obtained by difference between offered and rejected diet using a semi-analytical balance (Marte ${ }^{\circledR}$; accuracy: $0.001 \mathrm{~g}$ ). Relative intake (RI) was calculated by the ration food intake and body weight of the animal. Food efficiency coefficient (FEC) was the ratio between weight gain and food consumption. Protein intake (PI) was obtained as food intake multiplied by the protein content of the diet. All measurements were evaluated weekly.

\begin{tabular}{|c|c|c|c|}
\hline Ingredients (g/100g) & Casein diet & Egg White diet & Protein-free diet \\
\hline Corn starch ( $>87 \%$ carbohydrate) & 60.95 & 60.75 & 73.25 \\
\hline Casein (83\% protein) & 12.00 & - & - \\
\hline Egg white ( $80 \%$ protein) & - & 12.50 & - \\
\hline Sucrose & 10.00 & 10.00 & 10.00 \\
\hline Soy oil & 7.00 & 7.00 & 7.00 \\
\hline Cellulose & 5.00 & 5.00 & 5.00 \\
\hline Mineral mix (AIN93G) & 3.50 & 3.50 & 3.50 \\
\hline Vitamin mix (AIN93) & 1.00 & 1.00 & 1.00 \\
\hline L-Methionine & 0.30 & $0.00^{*}$ & 0.00 \\
\hline Choline bitartrate & 0.25 & 0.25 & 0.25 \\
\hline TBHQ & 0.0014 & 0.0014 & 0.0014 \\
\hline Total (g) & 100.00 & 100.00 & 100.00 \\
\hline Total energy (kcal/g) & 3.63 & 3.58 & 3.60 \\
\hline \multicolumn{4}{|c|}{ Composition of macronutrients according to total energy (\%) } \\
\hline Protein & 11.4 & 11.1 & 0.0 \\
\hline Carbohydrate & 70.8 & 71.5 & 82.4 \\
\hline Lipid & 17.0 & 17.4 & 17.6 \\
\hline
\end{tabular}

Tabla 1. Composición de las dietas experimentales ofrecidas a los animales durante el estudio.

Table 1. Composition of the experimental diets offered to animals during the study. 
$\mathrm{RI}=$ food intake $(\mathrm{g}) / \mathrm{BW}(\mathrm{g})$

$\mathrm{FEC}=($ final BW $(\mathrm{g})-$ initial BW $(\mathrm{g})) /$ food intake $(\mathrm{g})$

$\mathrm{PI}=$ food intake $(\mathrm{g}) \times$ percent of protein diet $(\%)$

\section{In vivo evaluation of protein quality}

Dietary protein quality was determined by the protein efficiency ratio (PER) and the net protein ratio (NPR). PER represents the ratio between weight gain and protein intake of the animal, being obtained at the end of 28 day of the diet consumption. NPR is calculated by the sum of body weight gain of the test group with the weight loss of protein free group divided by protein intake of the test group after 14 day of dietary consumption. Thus, NPR is considered more sensitive to determined dietary protein quality.

PER= BW gain of the test group $(\mathrm{g}) /$ protein intake by test group $(\mathrm{g})$

NPR $=(B W$ gain of the test group $(g)+B W$ loss of proteinfree group $(\mathrm{g})$ )/protein intake by teste group $(\mathrm{g})$

\section{Biochemical profile}

The rats were euthanized by decapitated on $56^{\text {th }}$ day of life. Blood samples from trunk were collected in sterile eppendorfs. Serum was obtained after centrifugation at $6000 \mathrm{rpm}$ during $20 \mathrm{~min}$ (Sprout model, Healthrow Scientific ${ }^{\circledR}$, Vernon Hills, Illinois, USA) and stored at $-82{ }^{\circ} \mathrm{C}$ until analysis. Glucose, creatinine, triglycerides, and total cholesterol were measured by enzymatic colorimetric system for determination with endpoint reaction (Liquiform Labtest ${ }^{\circledR}$, Lagoa Santa, Minas Gerais, Brazil). Absorbance reading was performed on the microplate spectrophotometer EPOCH тм (BIOTEK ${ }^{\circledR}$, Winooski, Vermont, USA). All analyzes were performed in triplicate.

\section{Organs and tissues weight}

After the euthanasia, an abdominal incision was made to collect the organs (liver, heart, brain, lungs, spleen, kidney and adrenal gland) and tissues (soleus muscle, extensor digitorum longus muscle and retroperitoneal adipose tissue) that were quickly removed and weighed in semi-analytical balance (Marte ${ }^{\circledR}$; accuracy: $0.001 \mathrm{~g}$ ). Subsequently, the relative weight of organs and tissues was calculated by relation between their absolute weight and body weight (BW).

Relative weight $(\%)=($ organ or tissue absolute weight $(g)) /$ $\mathrm{BW}(\mathrm{g})) \times 100$

\section{Statistical analysis}

Data normality was analyzed by D'Agostino \& Pearson test. Murinometrics measurements and food intake were analyzed by repeated measures two-way ANOVA (diet and time) followed by Bonferroni's post hoc test. PER, NPR, biochemical profile, absolute and relative weight of organs/ tissues data was analyzed by two-tailed Student's t test. All results were represented as mean \pm standard error mean (SEM). Significant difference was maintained at $\mathrm{p} \leq 0.05$. Data analysis and graphs were performed using the statistical program GraphPad Prism $6{ }^{\circledR}$ (GraphPad Software Inc., La Jolla, CA, USA).

\section{Results}

\section{Murinometric measurements}

Body weight of the egg white group was lower than casein group only at the two last measured days on $46^{\text {th }}(\mathrm{p}<0.05)$ and $53^{\text {th }}$ postnatal day $(\mathrm{p}<$ 0.001 ) (Fig. 1A). There was no difference in body length, BMI, and percentage of body weight gain between groups (Figs. 1B, 1C and 1D).

\section{Food intake parameters}

There was no difference between groups in absolute food intake during nutritional manipulation (Fig. 2A). However, relative food intake was increased in EW group in $4^{\text {th }}$ and $5^{\text {th }}$ week $(\mathrm{p}<0.05)$ (Fig. 2B). Feed efficiency coefficient showed a reduction in the EW group in $4^{\text {th }}(\mathrm{p}<0.05)$ and $6^{\text {th }}$ week $(\mathrm{p}<0.01)$ (Fig. $2 \mathrm{C})$. No significant difference was shown in the protein intake (Fig. 2D).

\section{In vivo protein quality evaluation}

Protein efficacy ratio (PER) and net protein ratio (NPR) were used to determine dietary protein quality. Egg white group showed lower PER $(\mathrm{p}<$ $0.001)$ and NPR $(\mathrm{p}<0.01)$ than casein group $(\mathrm{Ta}-$ ble 2).

\begin{tabular}{lccl}
\hline $\begin{array}{c}\text { Protein quality } \\
\text { indicator }\end{array}$ & $\begin{array}{c}\text { Casein diet } \\
(\mathbf{n}=\mathbf{1 0})\end{array}$ & $\begin{array}{c}\text { Egg white diet } \\
(\mathbf{n}=\mathbf{1 0})\end{array}$ & $\boldsymbol{P}$ value \\
\hline PER & $3.65 \pm 0.14$ & $2.98 \pm 0.05$ & $<0.001$ \\
NPR & $3.36 \pm 0.16$ & $2.68 \pm 0.09$ & $<0.01$ \\
\hline
\end{tabular}

Tabla 2. Calidad de la proteína en la dieta por métodos biológicos. Media \pm EEM.

Table 2. Dietary protein quality by biological methods. Mean \pm SEM.

\section{Serum biochemical profile}

No significant differences were found in serum biochemical parameters evaluated, except for cre- 

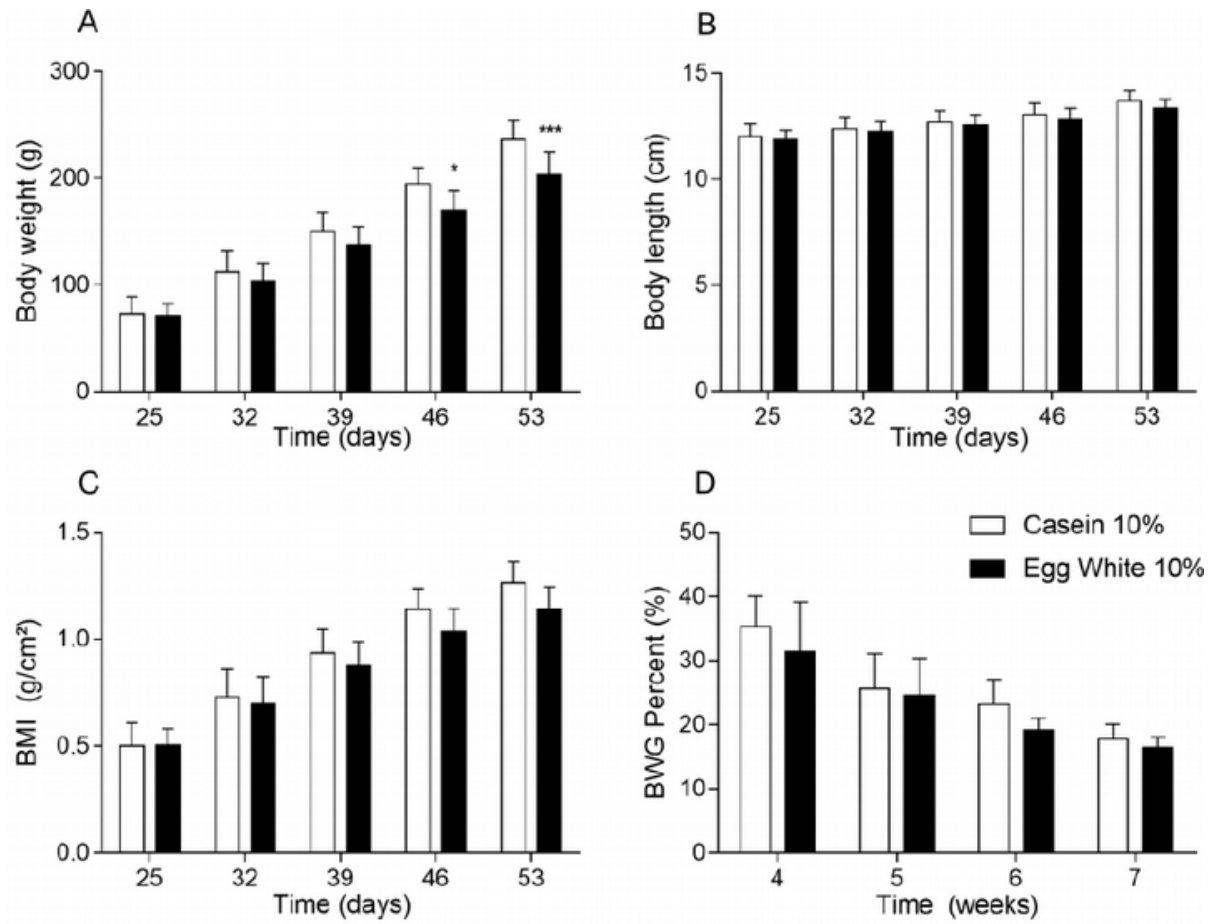

Figura 1. Evolución de las mediciones murinométricas durante el estudio. Se evaluaron semanalmente: A: peso corporal; B: longitud corporal; C: índice de masa corporal; D: porcentaje de ganancia de peso corporal. Caseína (control, $\mathrm{n}=10$ ) y clara de huevo (experimental, $\mathrm{n}=10)$. Los valores como media \pm EEM. Datos analizados por RM-ANOVA bidireccional y prueba de Bonferroni. *p $<0,05 ;{ }^{* * *}<<0,001$.

Figure 1. Murinometrics measurements evolution during the study. They were evaluated weekly: A: Body weight; B: body length; C: body mass index; D: body weight gain percent. Casein (control, $\mathrm{n}=10$ ) and Egg white (experimental, $\mathrm{n}=10$ ). Values are presented as mean $\pm \mathrm{SEM}$. Data were analyzed by RM two-way ANOVA followed by Bonferroni's test. ${ }^{*} \mathrm{p}<0.05 ;{ }^{* * *} \mathrm{p}<0.001$.

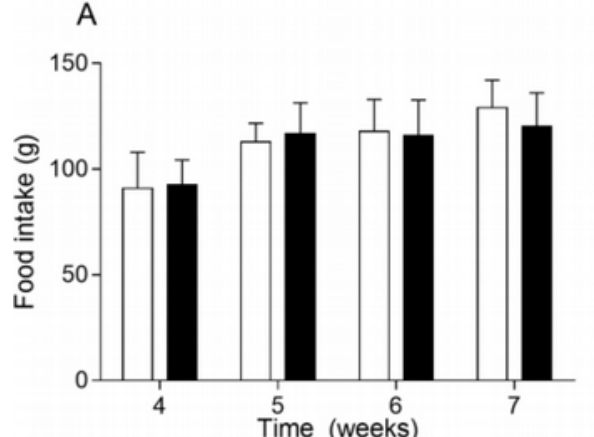

C

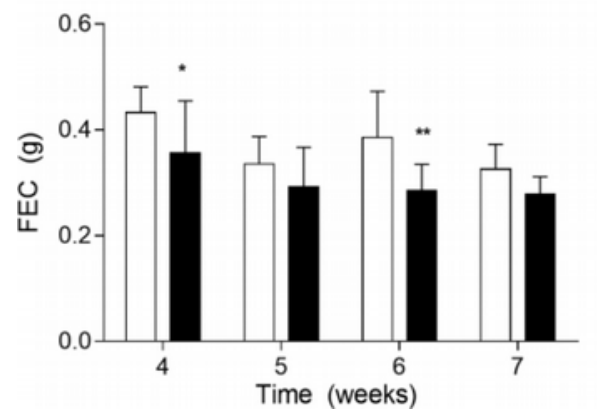

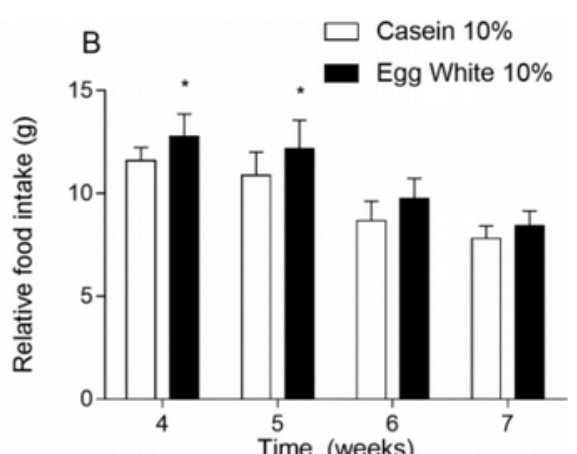

D

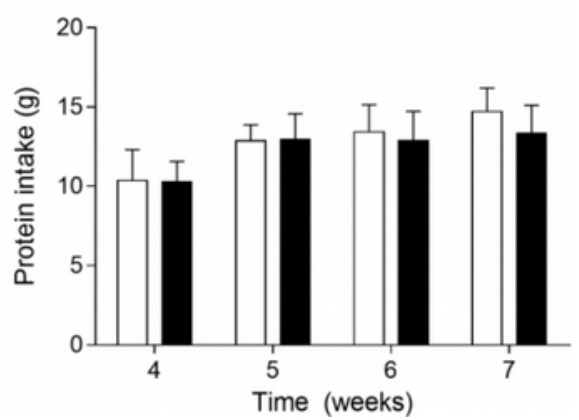

Figura 2. Mediciones de ingesta de alimentos de animales durante las 4 semanas para cada grupo. A: ingesta semanal de alimentos; B: ingesta relativa de alimentos; C: coeficiente de eficiencia alimentaria; D: ingesta de proteínas. Los grupos según la dieta experimental son caseína (control, $\mathrm{n}=0$ ) y clara de huevo (experimental, $\mathrm{n}=10$ ). Los valores como media \pm EEM. Datos analizados por RM-ANOVA bidireccional y prueba de Bonferroni. * $\mathrm{p}<0,05 ; * * \mathrm{p}<0,001$.

Figure 2. Animals food intake measurements during the 4 weeks for each group. A: weekly food intake; B: relative food intake; D: food efficiency coefficient; D: protein intake. The groups according to experimental diet are casein (control, $\mathrm{n}=10$ ) and egg white (experimental, $\mathrm{n}=10$ ). The values are presented as the mean \pm SEM. Data were analyzed by RM two-way ANOVA followed by a Bonferroni's test. * $\mathrm{p}<0.05$; $* * \mathrm{p}<0.01$. 
atinine that was elevated in EW group $(\mathrm{p}<0.05)$ (Table 3).

\section{Absolute and relative organs and tissues weight}

Liver absolute weight was lower in egg white group than casein group $(\mathrm{p}<0.01)$ (Table 3$)$. However, it was observed an increase in relative weight in brain, heart $(\mathrm{p}<0.001)$, kidney and EDL muscle $(\mathrm{p}<0.05)$ in EW group (Table 4).

\section{Discussion}

In the present study, we evaluated in vivo efficacy of lyophilized egg white as a substitute for casein in elaboration to diet based on AIN93 recommendations. The main results EW was classified as protein source of high biological value, according to NPR and PER indicators, despite its inferior quality compared to control diet. These outcomes were confirmed by reduction in body weight at 46 and $53 \mathrm{~d}$ of life, lower feed efficiency ratio at the 4th and 6th week of life, despite the increase in relative intake at the 4th and 5th week in the EW group. These animals also showed increased relative weights of the heart, kidney, brain and EDL muscle. The biochemical profile showed an increase in serum creatinine concentrations in the EW group.

According to protein quality indicators (NPR and PER) and comparing egg white (10\% protein) to casein (10\% protein) diets, EW underperformed through the imbalance between protein intake ratio and body weight of animals. The PER and

\begin{tabular}{lccc}
\hline Biochemical parameter & $\begin{array}{c}\text { Casein diet } \\
(\mathbf{n}=\mathbf{1 0})\end{array}$ & $\begin{array}{c}\text { Egg white diet } \\
(\mathbf{n = 1 0 )}\end{array}$ & $\boldsymbol{P \text { value }}$ \\
\hline Glucose $(\mathrm{mg} / \mathrm{dL})$ & $123.5 \pm 6.493$ & $124.4 \pm 4.529$ & 0.913 \\
Creatinine $(\mathrm{mg} / \mathrm{dL})$ & $0.401 \pm 0.033$ & $0.492 \pm 0.027$ & $<0.05$ \\
Triglycerides $(\mathrm{mg} / \mathrm{dL})$ & $76.12 \pm 8.467$ & $70.89 \pm 10.200$ & 0.698 \\
Total Cholesterol $(\mathrm{mg} / \mathrm{dL})$ & $36.95 \pm 4.068$ & $31.86 \pm 2.298$ & 0.291 \\
\hline
\end{tabular}

Tabla 3. Perfil bioquímico en suero de ratones machos. Media \pm EEM.

Table 3. Serum biochemical profile of rats. Mean \pm SEM.

\begin{tabular}{lccc}
\hline Organ and tissue weight & $\begin{array}{c}\text { Casein diet } \\
(\boldsymbol{n}=\mathbf{1 0})\end{array}$ & $\begin{array}{c}\text { Egg White diet } \\
(\boldsymbol{n}=\mathbf{1 0})\end{array}$ & $\boldsymbol{P}$ value \\
\hline Retroperitoneal adipose tissue (g) & $1.152 \pm 0.1284$ & $0.967 \pm 0.1252$ & 0.316 \\
Retroperitoneal adipose tissue (\%) & $0.491 \pm 0.0544$ & $0.481 \pm 0.0663$ & 0.091 \\
Soleus muscle (g) & $0.113 \pm 0.0187$ & $0.097 \pm 0.0054$ & 0.424 \\
Soleus muscle (\%) & $0.048 \pm 0.0076$ & $0.048 \pm 0.0026$ & 0.985 \\
EDL muscle (g) & $0.092 \pm 0.0044$ & $0.081 \pm 0.0035$ & 0.075 \\
EDL muscle (\%) & $0.039 \pm 0.0020$ & $0.047 \pm 0.0026$ & $<0.05$ \\
Brain (g) & $1.560 \pm 0.1768$ & $1.727 \pm 0.7432$ & 0.395 \\
Brain (\%) & $0.735 \pm 0.0264$ & $0.898 \pm 0.0280$ & $<0.001$ \\
Lung (g) & $1.481 \pm 0.0702$ & $1.347 \pm 0.0599$ & 0.163 \\
Lung (\%) & $0.629 \pm 0.0307$ & $0.666 \pm 0.0311$ & 0.407 \\
Heart (g) & $1.051 \pm 0.0303$ & $1.042 \pm 0.0399$ & 0.862 \\
Heart (\%) & $0.445 \pm 0.0096$ & $0.490 \pm 0.0050$ & $<0.001$ \\
Liver (g) & $11.30 \pm 0.4580$ & $9.51 \pm 0.3310$ & $<0.01$ \\
Liver (\%) & $4.803 \pm 0.2180$ & $4.699 \pm 0.1846$ & 0.720 \\
Kidney (g) & $0.998 \pm 0.0220$ & $0.966 \pm 0.3996$ & 0.488 \\
Kidney (\%) & $0.423 \pm 0.0067$ & $0.477 \pm 0.0195$ & $<0.05$ \\
Spleen (g) & $1.111 \pm 0.1188$ & $0.872 \pm 0.0682$ & 0.099 \\
Spleen (\%) & $0.473 \pm 0.0499$ & $0.433 \pm 0.0376$ & 0.523 \\
Adrenal gland (g) & $0.032 \pm 0.0029$ & $0.036 \pm 0.0032$ & 0.438 \\
Adrenal gland (\%) & $0.014 \pm 0.0012$ & $0.018 \pm 0.0016$ & 0.058 \\
\hline
\end{tabular}

Tabla 4. Peso absoluto y relativo de órganos y tejidos. Media \pm EEM.

Table 4. Absolute and relative weight of organs and tissues. Mean \pm SEM. 
NPR values indicates that EW protein was classified as a high biological value protein, similar values were more frequently observed in high biological value plant proteins such as okara from soymilk (PER:2.75; NPR:3.12) or soy-enriched cereals (PER:2.1-2.3) (Boschero et al. 2014, Acevedo-Pacheco \& Serna-Saldívar 2016). The ingredients used for elaboration to experimental diets may present different results in the animal growth pattern, although considered of high biological value (Moraes et al. 2012). Despite the same amount, the ingredients may have different amino acid compositions and protein structures that may impair their performance (Bai et al. 2016)

PER and NPR are indicators that can estimate the capacity of the protein ingested to influence animal's weight gain. However, when the animal is exposed to proteins that have a low efficiency, other nutrients must be prioritized by the organism to maintain the growth in critical phases (Ma et al. 2005, Lipina \& Hundal 2017). So, despite the inferior performance of the EW protein, a possible optimization of the other nutrients absorption and utilization could explain the absence of difference in some growth parameters, such as weight gain and length (Hornicket al. 2000). On the other hand, assessment of protein quality used in this study presents some limitations, such as quantify nitrogen balance (Hoffman \& Falvo 2004). Thus, several methods can be applied in complementary investigation to biological value of dietary proteins, such as net protein utilization (NPU) or biological value (BV) (AcevedoPacheco \& Serna-Saldívar 2016, Anyalogbu et al. 2020). In both methods the protein retention is measured through of relation between absorbed and excreted nitrogen, determining with more accuracy the protein efficiency (Hoffman \& Falvo 2004).

The impair on performance in protein quality was confirmed by result in absolute body weight of rats. The animals from EW group were lighter than the casein group, presenting an average difference of $14 \%$. Our results corroborate those described by Báez-Saldaña et al. (2009) who also observed a reduction in body weight of the EW group (30\% protein) starting on 3rd week of intervention in 21-day-old mice, although there was no difference in food intake (Báez-Saldaña et al. 2009). This reduction in body weight was also observed in adult humans fed an egg white diet for 28 days (Mock DM et al. 2002). Our animals showed no difference in body weight gain and retroperitoneal adipose tissue, similar results were observed in young rats fed egg white or casein diet for 4 weeks (Matsuoka et al. 2017).

In relation to dietary intake parameters, the food efficacy coefficient was lower in EW, despite the increase in relative intake. In the first weeks, the animals can develop a compensatory mechanism to maintain the nitrogen balance through increase in relative food intake but not sustained it in the long term (Millward 2003). This acute response is related to the adaptive capacity in animal feeding behavior, seeking to meet their daily nutritional needs, respecting the characteristics of the diet, and preserving the proper growth of animals (Davidenko et al. 2013).

In post-euthanasia analyzes, it was observed that the absolute liver weight was lower in EW group animals. However, there was no significant difference in the relative weight of this organ between experimental groups, establishing a body weight ratio. The EW animals group showed an increase in the relative weight of the brain, heart, EDL muscle and kidney. This renal alteration was similar to those observed in adult rats, but submitted to high-protein diets (30-50\% protein), which presented an increase in absolute and relative weight caused by their higher metabolic requirement (Jean et al. 2001, Aparicio et al. 2013). However, no differences were observed in heart and liver weight, as well as in absolute body weight and soleus muscle between experimental groups (Jean et al. 2001, Matsuoka et al. 2017).

In this study, we observed an increase in creatinine content in EW group. The increased concentration of this metabolite also occurs in studies of chronic exposure to high-protein diet, indicating an overload in functioning of muscles, kidneys, and other organs (Salazar 2015). Organs related to protein metabolism respond morphologically according to protein quantity and quality (Aparicio et al. 2013). In this sense, essentials organs and tissues to protein metabolism, such as the heart, kidneys, and brain, shows structural and functional remodeling to maintain adequate growth and development according to nutrient availability (Dudley et al. 1996, Wells 2014, Kim 2016). This adaptive response is related to "metabolic capacity", which is a predictor of the organ's efficiency in maintaining homeostasis through the imposition of environmental insults, such as feed- 
ing (Wells 2010). As well as "metabolic load", which indicates the volume of stimulation that the organ supports to maintain the animal homeostasis (Wells 2010). This plastic characteristic occurs at critical periods, such as the growth phase of mammals, aimed at maintaining life (Dudley et al. 1996, Wells 2014, Kim 2016).

However, it is described in literature that chronic consumption of egg white causes the phenomenon called "egg white injury", which promotes deleterious effects on animal growth (BáezSaldaña et al. 2013, Yuasa et al. 2016). Therefore, egg white has a high avidin content, an antinutritional factor capable of complexing with biotin (vitamin B7), resulting in their reduced bioavailability (Hyánková et al. 2018). The deficiency of this vitamin may compromise the availability of trophic factors, such as insulin like growth factor1 (IGF-1), which acts synergistically with the mTOR pathway in promoting somatic growth through protein synthesis and lipogenesis (BáezSaldaña et al. 2009). It is also known that ingestion of egg white in relation to whole egg is not efficient in postprandial stimulation of muscle protein synthesis via the mTOR (Sawan et al. 2018). These trophic factors influence somatic growth by favoring skeletal muscle hypertrophy and promoting adipogenesis through inhibition of cell catabolism and positive nitrogen balance (Saxton \& Sabatini 2017). Thus, these somatic and physiological changes may be related to the lower body weight found in the final weeks of the present study.

Additionally, some methodological aspects of in vivo protein quality analysis should be discussed, such as the free protein group presence. In this sense, this group represents a necessary component to estimate the dietary protein contribution for the animal growth (Souza et al. 2006, Boschero et al. 2014). Exposure to a protein-free diet should be short-term (14 days) as deprivation of protein in long term can compromise the animal's health through malnutrition and leading to death (Carillo et al. 2014). Recent studies have also used free protein diet to analyze NPR (Souza et al. 2006, Boschero et al. 2014). However, some authors have proposed the use of diets contents $4 \%$ protein as a negative control of the experimental diet (Anyalogbu et al. 2020). This modification in the assessment can allows to obtain adequate results, while the animal receives some protein contribution (Anyalogbu et al. 2020).

\section{Conclusion}

In conclusion, our results showed that egg white does not represent an effective protein to replace casein in the elaboration of AIN93 diet. Although been classified as a high biological value protein, EW showed PER and NPR values more closed to biological value protein from plant source. This characteristic was well observed due to its lower efficiency in transform the protein intake in body weight gain. Increased relative weight from some organs related to protein metabolism was observed as well increased creatinine concentration. Taking together these findings may represent an overload in these organs function that could result in impaired function in future. Thus, other lowcost protein sources should be test in replacement of casein that could promote adequate animal growth.

\section{Acknowledgments}

We thank the NPlast (Unidade de Estudos em Nutrição e Plasticidade Fenotípica) and LENIB (Laboratório de Experimentação em Nutrição e Instrumentação Biomédica) for their technical support. This study was financed in part by Conselho Nacional de Desenvolvimento Científico e Tecnológico (CNPq), grant number 429610/2018-1) and Fundação de Amparo à Ciência e Tecnologia do Estado de Pernambuco (FACEPE), grant number APQ-0201-4.05/14. Wenicios Ferreira Chaves received a scholarship by $\mathrm{CNPq}$ (number 132530/2018-0). We thank Ms. Erika Vanesa Cadena Burbano for Spanish review.

\section{References}

Acevedo-Pacheco L \& Serna-Saldívar SO. 2016. In vivo protein quality of selected cereal-based staple foods enriched with soybean proteins. Food \& Nutrition Research 60: 1-9. https://doi.org/10.3402/fnr.v60.31 $\underline{382}$.

Adolf Lutz Institute. 2008. Normas analíticas do Instituto Adolf Lutz. Métodos físico-químicos para análises de alimentos. São Paulo: Instituto Adolf Lutz.

Anyalogbu EAA, Onyeike EN \& Nweje-Anyalowu PC. 2020. In-vivo protein quality assessment of macerated African elemi pulp eaten as masticatories in Eastern Nigeria. Bulletin of the National Research Centre 44: [5]. https://doi.org/10.1186/s42269-0190242-3.

Aparicio VA, Nebot E, García-del Moral R, MachadoVílchez M, Porres JM, Sánchez C \& Aranda P. 2013. Dietas hiperproteicas y estado renal en ratas. Nutri- 
ción Hospitalaria 28(1): 232-237. http://dx.doi.org/ 10.3305/nh.2013.28.1.6165.

Báez-Saldaña A, Gutiérrez-Ospina G, Chimal-Monroy J, Fernandez-Mejia C \& Saavedra R. 2009. Biotin deficiency in mice is associated with decreased serum availability of insulin-like growth factor-I. European Journal of Nutrition 48(3): 137-144. https://doi.org/ 10.1007/s00394-009-0773-8.

Báez-Saldaña A, Salcedo PH, Oca MAPM de, Meléndez-Herrera E, Gutiérrez-Ospina G, Fuentes-Farías AL \& Gómez-Chavarín M. 2013. Differential effect of biotin on carboxylase activity and mice skeletal muscle metabolism. Advances in Bioscience and $\mathrm{Bi}$ otechnology 4(7): 4 3-50. http://dx.doi.org/10.4236/ abb.2013.47A2006.

Bai M, Qin G, Sun Z \& Long G. 2016. Relationship between molecular structure characteristics of feed proteins and protein in vitro digestibility and solubility. Asian-Australasian Journal of Animal Sciences 29(8): 1159-1165. https://doi.org/10.5713/ajas.15. 0701.

Boschero AC, Ramalho A de FS, Veloso RV, Lemes SF de Almeida APC, Latorraca MQ, . . Lima FM. 2014. Nutritional recovery with okara diet prevented hypercholesterolemia, hepatic steatosis and glucose intolerance. International Journal of Food Sciences and Nutrition 65(6): 745-753. https://doi.org/10.3109/ 096374866.2014.898259.

Brown NM \& Setchell KDR. 2001. Animal models impacted by phytoestrogens in commercial chow: Implications for pathways influenced by hormones. Laboratory Investigation 81(5): 735-747. https:// doi.org/10.1038/labinvest.3780282.

Carrillo E, Jimenez MA, Sanchez C, Cunha J, Martins, CM, Sevá AP \& Moreno J. 2014. Protein malnutrition impairs the immune response and influences the severity of infection in a hamster model of chronic visceral leishmaniasis. PLoS One 9: 1-10. https:// doi.org/10.1371/journal.pone.0089412.

Chalvon-Demersay T, Blachier F, Tomé D \& Blais A. 2017. Animal Models for the Study of the Relationships between Diet and Obesity: A Focus on Dietary Protein and Estrogen Deficiency. Frontiers in Nutrition $4 \quad$ (5): $1-13$ https://doi.org/10.3389/fnut.2017.00005.

Davidenko O, Darcel N, Fromentin G \& Tomé D. 2013. Control of protein and energy intake - Brain mechanisms. European Journal of Clinical Nutrition 67(5): 455-461. https://doi.org/10.1038/ejcn.2013.73.

Derzi SH, Moore A, Elgueta MF, Moustafa M, Schricker T \& Tran DQ. 2012. Protein quality evaluation of two rice- and milk-based weaning foods. Electronic Physician 4(1): 454-460. http://dx.doi.org/10.14661/ 2012.454-460.

Desai M \& Hales CN. 1997. Role of Fetal and Infant Growth in Programming Metabolism in Later Life. Biological reviews of the Cambridge Philosophical Society 72(2): 329-348. http://dx.doi.org/10.1017/ S0006323196005026.

Dudley MA, Heath JP, Pond WG, Mersmann HJ, Burrin DG, Ellis KJ, . . . Sheng H-P. 1996. Severe Protein Deficiency and Repletion Alter Body and Brain Composition and Organ Weights in Infant Pigs. The
Journal of Nutrition 126(1): 290-302. https://doi.org/ 10.1093/jn/126.1.290.

Gerage JM, Meira APG \& da Silva MV. 2017. Food and nutrition security: pesticide residues in food. Nutrire 42(1): 1-9. http://dx.doi.org/10.1186/s41110-016-00 28-4.

Gibbs VK \& Smith DL. 2016. Nutrition and energetics in rodent longevity research. Experimental Gerontology 86: 90-96. https://doi.org/10.1016/j.exger.2016.04. $\underline{004}$.

Hoffman JR \& Falvo MJ. 2004. Protein - Which is best? Journal of Sports Science \& Medicine 3(3): 118-130.

Hornick JL, Eenaeme CV, Gérard O, Dufrasne I \& Istasse L. 2000. Mechanisms of reduced and compensatory growth. Domestic Animal Endocrinology 19: 121-132. https://doi.org/10.1016/s0739-7240(00) $\underline{00072-2}$

Hyánková L, Javůrková V, Krkavcová E, Hyršl P \& Kreisinger J. 2018. The hidden function of egg white antimicrobials: egg weight-dependent effects of avidin on avian embryo survival and hatchling phenotype. Biology Open 7(4): 1-9. https://doi.org/10.1242/bio. $\underline{031518 .}$.

Jean C, Rome S, Mathé V, Huneau J-F, Aattouri N, Fromentin G, Achagiotis CL \& Tomé D. 2001. Metabolic Evidence for Adaptation to a High Protein Diet in Rats. The Journal of Nutrition 131(1): 91-98. https:// doi.org/10.1093/jn/131.1.91.

Kim JB. 2016. Dynamic cross talk between metabolic organs in obesity and metabolic diseases. Experimental \& Molecular Medicine 48(3): 1-2. http://dx. doi.org/10.1038/emm.2015.119.

Lipina C \& Hundal HS. 2017. Lipid modulation of skeletal muscle mass and function. Journal of Cachexia, Sarcopenia Muscle 8: 190-201. https://doi.org/ 10. 1002/jcsm.12144.

Ma Y, Olendzki B, Chiriboga D, Hebert JR, Li Y, Li W, ... Ockene, IS. 2005. Association between Dietary Carbohydrates and Body Weight. American Journal of Epidemiology 161: 359-367. https://doi.org/10.1093/ aje/kwi051.

Mark PJ, Sisala C, Connor K, Patel R, Lewis JL, Vickers MH, . . Sloboda DM. 2011. A maternal high-fat diet in rat pregnancy reduces growth of the fetus and the placental junctional zone, but not placental labyrinth zone growth. Journal of Developmental Origins of Health and Disease 2(1): 63-70. https://doi.org/ 10.1017/S2040174410000681.

Martus W, Kim D, Garvin JL \& Beierwaltes WH. 2005. Commercial rodent diets contain more sodium than rats need. American Journal of Physiology Renal Physiology 288(2): F428-F431. https://doi.org/10. 1152/ajprenal.00310.2004.

Matsuoka R, Shirouchi B, Umegatani M, Fukuda M, Muto A, Masuda Y, . . . Sato M. 2017. Dietary eggwhite protein increases body protein mass and reduces body fat mass through an acceleration of hepatic $\beta$-oxidation in rats. British Journal of Nutrition 118(6): 423-430. https://doi.org/10.1017/s00071145 17002306.

Matsuoka R, Imura MK, Uto AM, Asuda YM, Ato MS \& Maizumi KI. 2008. Mechanism for the CholesterolLowering Action of Egg White Protein in Rats. 
Journal Bioscience, Biotechnology, and Biochemistry 72(6): 1506-1512. https://doi.org/10.1271/bbb. 80016.

Millward DJ. 2003. An adaptive metabolic demand model for protein and amino acid requirements. British Journal of Nutrition 90(2): 249-260. https://doi. org/10.1079/bjin2003924.

Millward DJ. 2012. Amino acid scoring patterns for protein quality assessment. British Journal of Nutrition 108: S31-S43. https://doi.org/10.1017/ S000711451 2002462.

Moraes ÉA, Queiroz VAV, Shaffert RE, Costa NMB, Nelson JD, Ribeiro SMHR \& Martino HSD. 2012. In vivo protein quality of new sorghum genotypes for human consumption. Food Chemistry 134(3): 1549-1555. https://doi.org/10.1016/j.foodchem.2012.03.079.

Morgane PJ, Austin-LaFrance R, Bronzino J, Tonkiss J, Díaz-Cintra S, Cintra L, . . Galler JR. 1993. Prenatal malnutrition and development of the brain. Neuroscience \& Biobehavioral Reviews 17(1): 91-128. https://doi.org/10.1016/S0149-7634(05)80234-9.

Neufeld J, Utioh A, Medina G, Franczyk A, Appah P, Nosworthy M, . . . Frohlich P. 2018. Effect of Processing on the In Vitro and In Vivo Protein Quality of Beans (Phaseolus vulgaris and Vicia Faba). Nutrients 10(6): 671. https://doi.org/10.3390/nu10060671.

Norton LE, Wilson GJ, Moulton CJ \& Layman DK. 2016. Meal Distribution of Dietary Protein and Leucine Influences Long-Term Muscle Mass and Body Composition in Adult Rats. The Journal of Nutrition 147(2): 195-201. https://doi.org/10.3945/jn.116.2317 $\underline{79}$.

Reeves PG. 1993. Committee Report AIN-93 Purified Diets for Laboratory Rodents: Final Report of the American Institute of Nutrition Ad Hoc Writing Committee on the Reformulation of the AIN-76A Rodent Diet. The Journal of Nutrition 123: 1939-1951. https://doi.org/10.1093/jn/123.11.1939.

Salazar JH. 2015. Overview of Urea and Creatinine. Laboratory Medicine 45(1): e19-e20. https://doi.org/ 10.1309/LM920SBNZPJRJGUT.
Sawan SA, Vliet S, West DWD, Beals JW, Paluska SA, Burd NA \& Moore DR. 2018. Whole egg, but not egg white ingestion, induces mTOR co-localization with the lysosome after resistance exercise. American Journal of Physiology Cell Physiology 315(4): 537543. https://doi.org/10.1152/ajpcell.00225.2018.

Saxton RA \& Sabatini DM. 2017. mTOR Signaling in Growth, Metabolism, and Disease. Cell 168(6): 960976. https://doi.org/10.1016/j.cell.2017.02.004.

Souza J, Mauro AK, Carvalho HA, Monteiro MRP \& Martino HSD. 2006. Qualidade protéica de multimisturas distribuídas em Alfenas, Minas Gerais, Brasil. Revista de Nutrição 19: 685-692. http://dx.doi.org/10. 1590/S1415-52732006000600005.

Uyemura SA, Stopper H, Martin FL \& Kannen V. 2017. A Perspective Discussion on Rising Pesticide Levels and Colon Cancer Burden in Brazil. Frontiers in Public Health 5(273): 1-8. https://doi.org/10.3389/fpubh. 2017.00273.

Wells JCK. 2010. Maternal capital and the metabolic ghetto: An evolutionary perspective on the transgenerational basis of health inequalities. American Journal of Human Biology 22(1):1-17. https://doi.org/ 10.1002/ajhb.20994.

Wells JCK. 2014. Adaptive variability in the duration of critical windows of plasticity Implications for the programming of obesity. Evolution, Medicine, \& Public Health 2014(1): 109-121. https://doi.org/10.1093/ emph/eou019.

Mock DM, Henrich CL, Carnel N \& Mock NI. 2002. Indicators of marginal biotin deficiency and repletion in humans: validation of 3-hydroxyisovaleric acid excretion and a leucine challenge. American Journal of Clinical Nutrition 76(5): 1061-1068. https://doi.org/ 10.1093/ajcn/76.5.1061.

Yuasa M, Aoyama Y, Shimada R, Sawamura H, Ebara S, Negoro M, ... Watanabe T. 2016. Effects of biotin deficiency on biotinylated proteins and biotin-related genes in the rat brain. Journal of Nutrition Science and Vitaminology 62(2): 81-87. https://doi.org/10. 3177/jnsv.62.81. 